RAD Conference Proceedings, vol. 5, pp. 48-52, 2021

ISSN 2466-4626 (online) | DOI: 10.21175/RadProc.2021.09

www.rad-proceedings.org

\title{
DYNAMIC TEST OF ALKALINE HLW PROCESSING WITH HYDROXYCALIX[6]ARENES BASED SOLVENT
}

\author{
Igor V. Smirnov',2,3*, Maria D. Karavan',2,3, Albert Z. Yumaguen²,3 \\ ${ }^{1}$ Khlopin Radium Institute, Russia, St. Petersburg \\ ${ }^{2}$ Ozersk Institute of Technology, Ozersk, Russia \\ 3Saint-Petersburg State University, Saint-Petersburg, Russia
}

\begin{abstract}
Several extraction systems based on functionalized calixarenes in mixed fluorinated diluents were examined. Technological flowsheets for radioactive waste processing with these extraction systems were developed and tested. It is shown that under the selected conditions one can achieve decontamination factors from cesium isotopes and alpha-emitters, sufficient for converting high-level waste of the "Mayak" Production Association into the low-level category with the subsequent possibility of their disposal at near-surface sites.
\end{abstract}

Key words: Solvent extraction, alkaline $H L W$ processing, hydroxycalix[n]arenes, cesium-137, transuranium elements

\section{INTRODUCTION}

Despite the fact that most of the nuclear industry wastes around the world are based on nitric acid (in particular, Purex process raffinates), alkaline wastes are also a problem (Hanford and Savannah River sites in the USA, "Mayak" Production Association in Russia) and potential wastes of the CARBEX process, developed for the reprocessing of spent nuclear fuel in alkaline media [1], [2].

The amount of accumulated alkaline high level wastes (HLW) is significantly less than that of acidic ones, but their processing is a very difficult technological task due to the extremely high content of salts of non-radioactive elements. To date, only "Mayak" Production Association stores more than $18000 \mathrm{~m}^{3}$ of alkaline HLW, generated during the implementation of the Atomic Project of the USSR. These wastes contain up to $5 \mathrm{~mol} / \mathrm{L}$ of sodium hydroxide, nitrate and nitrite, about $5 \times 10^{10} \mathrm{~Bq} / \mathrm{L}{ }^{137} \mathrm{Cs}$, $10^{6}-10^{8} \mathrm{~Bq} / \mathrm{L}$ of actinides (i.e. americium and plutonium), and ${ }^{90} \mathrm{Sr}$ [3]. Recovery of $99.8 \%$ of radionuclides from alkaline HLW can help to transfer them to the category of low-level waste (LLW) and significantly simplify their final disposal.

Since alkaline wastes in Russia and, for example, in the USA, differ in their origin and, accordingly, in composition, the requirements for their processing also differ. In particular, according to the CSSX process developed in the USA, the technological scheme includes 18 stages: 7 stages of extraction, 7 stages of stripping and stages of washing/regeneration, but only ${ }_{137} \mathrm{Cs}$ is removed, and to achieve the requirements, high decontamination factors and high $\mathrm{Cs} / \mathrm{Na}$ separation factor is needed [4]. CSSX-process is based on a complicated extraction mixture, containing $0.05 \mathrm{~mol} / \mathrm{L}$ MaxCalix as an extractant, $0.5 \mathrm{~mol} / \mathrm{L}$ Cs-7SB as a modifier, $0.003 \mathrm{~mol} / \mathrm{L} \mathrm{LIX}{ }^{\circledR} 79$ as a suppressor and Isopar $\mathrm{L}$ as a diluent.

At the "Mayak" PA, the existing way of alkaline HLW processing is direct vitrification followed by glass isolation in geological formations. Recovery of a number of radionuclides would make it possible to reduce the waste activity to a level that would allow them to be cemented with subsequent isolation in near-surface storage facilities at ground level. To implement such a process, it is necessary to simultaneously remove cesium, strontium and transuranium elements (TUE); however, in contrast to the American version of processing, average values of decontamination factors are sufficient and high selectivity $\mathrm{Cs} / \mathrm{Na}$ is not necessary. In fact, this means that the following decontamination factors must be

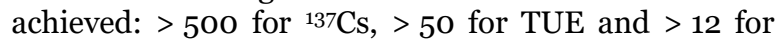
${ }^{90} \mathrm{Sr}$.

Hydroxycalix[n]arenes with high chemical and radiation resistance are promising extractants for the long-lived radionuclides recovery from alkaline media. We studied the regularities of ${ }^{137} \mathrm{Cs},{ }^{9} \mathrm{Sr}$ and ${ }^{241} \mathrm{Am}$ extraction from alkaline media with palkylcalix[n]arenes $(n=4,6,8) \quad[5]-[7] . \quad$ A general feature of these compounds is their insufficient solubility in most known organic diluents; therefore, modifications of the primary calixarene platform were made in order to preserve the extraction efficiency of the compounds towards to radionuclides and increase their solubility in organic diluents by introducing appropriate substituents into the molecule. Based on the results of preliminary studies, only 2 of them

\footnotetext{
*igor smirnov@khlopin.ru
} 
demonstrated sufficient extraction ability (due to their ability of aggregation) and good solubility and were chosen for static and dynamic tests on HLW (Fig. 1).<smiles>CCc1cc(CC(C)(C)C)c(O)c(C(C)(C)CC(C)(C)c2cc(C(C)(C)C)cc(CC(C)(C)C)c2O)c1</smiles>

Figure 1. Functionalized calix[n]arenes: calix[8]arene BN 6/2 $(\mathrm{N}=6, \mathrm{M}=2)$ and calix[6]arene IN6 $(\mathrm{N}=\mathrm{O}, \mathrm{M}=6)$

The main our goal was to develop a one-step process of long-lived radionuclides extraction from alkaline HLW by functionalized hydroxycalix[n]arenes.

\section{MATERIALS AND METHODS}

Calixarenes were synthesized in the "A. Butlerov Institute of Chemistry" (Kazan) under supervision of Prof. Igor S. Antipin. Synthesis and isolation of "mixed" tert-butyl-isononyl-calix[8]arene BN N/M (where $\mathrm{N}$ and $\mathrm{M}$ are the number of tert-butyl and isononyl substituents, respectively), as well as isononyl-calix[6]arene IN6 were conducted according to the methods from publications [5], [8].

\subsection{Static tests with real alkaline $H L W$}

General technological flowsheet for static test is presented in Fig. 2.

The flowsheet included joint extraction of TUE and cesium from alkaline HLW (4 contacts at stages E1 - E4 with fresh extractant, saturation of the extract after stage E1 with extractable elements (1 contact with fresh HLW, followed by joint stripping of radionuclides from saturated extract (3 contacts with stripping agent).

The total activity of alpha emitters in the original HLW was represented mainly by the radionuclides americium, curium, and plutonium. Cesium and strontium isotopes contributed to the total activity of beta emitters.

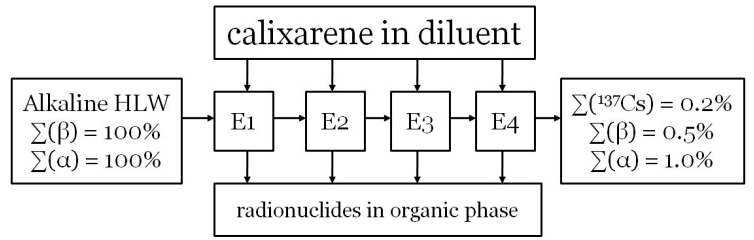

Figure 2. General technological flowsheet for static test

Table 1 shows the main features of the used extraction mixtures based on the "mixed" tert-butylisononyl-calix[8]arene $\mathrm{BN} \mathrm{6/2}$ and isononylcalix[6] arene IN6, as well as the characteristics of the processed HLW.
Table 1. Main features of extraction mixtures for static test and HLW, processed with these extractants

\begin{tabular}{|c|c|c|}
\hline № & Composition & Real HLW \\
\hline 1 & $\begin{array}{c}\mathrm{BN} \mathrm{6/2} \\
\text { o.01 mol/L in } \\
\text { perchloroethylene }\end{array}$ & $\begin{array}{c}\text { Real alkaline } \\
\text { decantate, diluted } \\
\text { twice and filtered. } \\
\mathrm{A} \beta \sim 3 \cdot 10^{10} \mathrm{~Bq} / \mathrm{L} \\
\mathrm{A}_{\alpha} \sim 7 \cdot 10^{4} \mathrm{~Bq} / \mathrm{L} \\
\mathrm{A}(134,137 \mathrm{Cs})- \\
2.2 \cdot 10^{10} \mathrm{~Bq} / \mathrm{L} \\
+\mathrm{Na}^{+} \mathrm{salts} \\
\left(\mathrm{OH}^{-}, \mathrm{NO}_{3}^{-}, \mathrm{NO}_{2}^{-},\right. \\
\left.\mathrm{AlO}_{2}^{-}, \mathrm{CrO}_{4}^{2-}\right)\end{array}$ \\
\hline 2 & $\begin{array}{c}\mathrm{BN} 6 / 2 \\
0.02 \text { mol/L in fluorinated } \\
\text { diluent: } \\
30 \% \text { vol. } m \text { - } \\
\text { nitrobenzotrifluoride } \\
\mathrm{H}\left(\mathrm{CF}_{2} \mathrm{CF}_{2}\right)_{3} \mathrm{CH}_{2} \mathrm{OBu}\end{array}$ & $\begin{array}{c}\text { Real alkaline } \\
\text { decantate } \\
\text { Non-filtered, } \\
\text { non-diluted } \\
\mathrm{A}\left({ }^{137 \mathrm{Cs})}\right)= \\
4.2 \cdot 10^{10} \mathrm{~Bq} / \mathrm{L} \\
\mathrm{A}(134 \mathrm{Cs})= \\
2.9 \cdot 10^{7} \mathrm{~Bq} / \mathrm{L} \\
\mathrm{A}_{\alpha} \sim 4.1 \cdot 10^{5} \mathrm{~Bq} / \mathrm{L} \\
\mathrm{A}_{\beta} \sim 4.3 \cdot 10^{10} \mathrm{~Bq} / \mathrm{L}\end{array}$ \\
\hline 3 & $\begin{array}{c}\text { IN6 } \\
\text { o.013 mol/L in mixed } \\
\text { diluent: } \\
13 \% \text { vol. } m \text { - } \\
\text { nitrobenzotrifluoride } \\
\mathrm{H}_{3} \mathrm{C} \\
32 \% \text { vol. } n \text {-tridecane } \mathrm{C}_{13} \mathrm{H}_{28}\end{array}$ & $\begin{array}{c}\text { Real alkaline } \\
\text { decantate } \\
\text { Non-filtered, non- } \\
\text { diluted } \\
\mathrm{A}(137 \mathrm{Cs})= \\
2.6 \cdot 10^{10} \mathrm{~Bq} / \mathrm{L} \\
\mathrm{A}_{\alpha} \sim 4 \cdot 5^{\circ} \cdot 10^{7} \mathrm{~Bq} / \mathrm{L} \\
+\mathrm{Na}^{+} \mathrm{salts}^{-} \\
\left(\mathrm{OH}^{-}, \mathrm{NO}_{3}^{-}, \mathrm{NO}_{2}^{-},\right. \\
\left.\mathrm{AlO}_{2}^{-}, \mathrm{CrO}_{4}^{2-}\right)\end{array}$ \\
\hline
\end{tabular}

\subsection{Dynamic test}

General technological flowsheet for dynamic test is presented on Fig. 3, composition of extraction mixture - in the Tab. 2.

The dynamic test included extraction of ${ }^{137} \mathrm{Cs}$ and $\alpha-$ emitting radionuclides at 10 stages of the extraction unit, followed by the re-extraction of ${ }^{137} \mathrm{Cs}$ and $\alpha$ emitting radionuclides at 6 stages of the block of reextraction.

recycled solvent

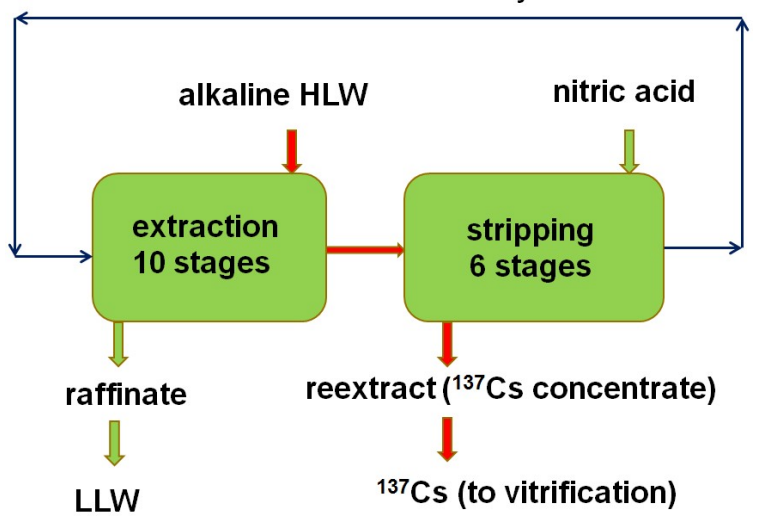

Figure 3. Dynamic test flowsheet 
Table 2. Composition of the extraction mixture used in the dynamic test and HLW composition

\begin{tabular}{|c|c|c|c|c|}
\hline Composition & \multicolumn{4}{|c|}{ Model alkaline HLW of "Mayak" PA } \\
\hline $\begin{array}{c}\text { IN6 } \\
\text { o.038 mol/L } \\
\text { in mixed } \\
\text { diluent: }\end{array}$ & \multicolumn{4}{|c|}{$\begin{array}{c}1.0 \cdot 10^{7} \mathrm{~Bq} / \mathrm{L}^{137 \mathrm{Cs}}+\text { stable } \\
\text { components: }\end{array}$} \\
\hline \multirow{3}{*}{$\begin{array}{c}\text { 10\% vol. } m- \\
\text { nitrobenzo- } \\
\text { trifluoride }\end{array}$} & Cation & $\mathrm{C}, \mathrm{g} / \mathrm{L}$ & Anion & $\mathrm{C}, \mathrm{g} / \mathrm{L}$ \\
\hline & $\mathrm{Na}^{+}$ & 100 & $\mathrm{NO}_{3}^{-}$ & 110 \\
\hline & $\mathrm{Al}^{3+}$ & 6.0 & $\mathrm{OH}^{-}$ & 43 \\
\hline \multirow{2}{*}{$\begin{array}{l}10 \% \text { vol. } \\
\text { diglyme }\end{array}$} & $\mathrm{Cr}^{6+}$ & 0.4 & $\mathrm{NO}_{2}^{-}$ & 35 \\
\hline & $\mathrm{Si}^{4+}$ & 0.2 & $\mathrm{SO}_{4}{ }^{2-}$ & 1.5 \\
\hline $\begin{array}{c}\text { tridecane } \\
\mathrm{C}_{13} \mathrm{H}_{28}\end{array}$ & & & & \\
\hline
\end{tabular}

\section{RESULTS AND DisCUSSION}

\subsection{Static tests}

Comparison of the data obtained during the static test is presented in Tab. 3 .

Table 3. Values of decontamination factors DF obtained for different extraction systems in a static test

\begin{tabular}{|c|c|c|c|}
\hline Noo & Solvent & \multicolumn{2}{|c|}{$\mathrm{DF}$} \\
\hline & & ${ }^{137} \mathrm{Cs}$ & $\sum(a)$ \\
\hline 1 & $\begin{array}{c}\mathrm{BN} 6 / 2 \\
0.01 \mathrm{~mol} / \mathrm{L} \text { in perchloroethylene }\end{array}$ & 40 & 3.5 \\
\hline 2 & $\begin{array}{c}\text { BN 6/2 } \\
0.02 \mathrm{~mol} / \mathrm{L} \text { in fluorinated } \\
\text { diluent } \\
(m-\mathrm{NBTF}+\mathrm{FE}-34,30: 70 \% \text { vol.) }\end{array}$ & 300 & 40 \\
\hline 3 & $\begin{array}{c}\text { IN6 } \\
\text { o.013 mol/L in mixed diluent } \\
(m-N B T F+\text { diglyme }+n- \\
\text { tridecane, } 13: 55: 32 \% \text { vol. })\end{array}$ & 15000 & 100 \\
\hline
\end{tabular}

In the case of a mixture based on calix[8]arene BN 6/2 in perchloroethylene, $98 \%$ of $\beta$ - and $90 \%$ of $\alpha$ emitting radionuclides are extracted from real HLW in 4 contacts. Complete re-extraction (99\%) is achieved with $1 \mathrm{~mol} / \mathrm{L}_{\mathrm{HNO}_{3}}$. At all stages, a rapid (<1 min) phase separation was observed without any third phase formation or interphase films.

For a system based on calix[8]arene $\mathrm{BN} 6 / 2$ in a mixed diluent (m-NBTF + FE-34) more than $99 \%$ of the total activity is re-extracted already at the first step of re-extraction with a mixture of $1 \mathrm{~mol} / \mathrm{L}$ aminoacetic acid $+1 \mathrm{~g} / \mathrm{L}$ DTPA. After 4 stages of extraction, less than $4 \cdot 1 \cdot 10^{7} \mathrm{~Bq} / \mathrm{L}$ of the total of $\beta$-active radionuclides $\left({ }^{137} \mathrm{Cs}\right.$ - less than $\left.1.2 \cdot 10^{7} \mathrm{~Bq} / \mathrm{L}\right)$ and less than $1.9 \cdot 10^{5} \mathrm{~Bq} / \mathrm{L}$ of the total of $\mathrm{a}$-active radionuclides remained in alkaline waste.
When cementing these liquid waste according to the technology adopted at the "Mayak" PA, each liter of the waste will yield approximately $3 \mathrm{~kg}$ of solid one with a specific activity of less than $1.4 \cdot 10^{4} \mathrm{~Bq} / \mathrm{L}$ of the sum of $\beta$-active radionuclides $\left({ }^{137} \mathrm{Cs}\right.$ - less than $0.3 \cdot 10^{4} \mathrm{~Bq} / \mathrm{L}$ ) and $0.6 \cdot 10^{2} \mathrm{~Bq} / \mathrm{L}$ of the sum of $\alpha$-active radionuclides, which practically coincides with the levels permissible for low-level waste of class 4, which is allowed to be disposed of in surface sites [9].

Thus, despite the fact that the required values of decontamination factors in the static test were not achieved with calixarene $\mathrm{BN} 6 / 2$, the extraction system based on this calixarene appears to be accessible and promising for the processing of alkaline HLW.

For the system based on isononyl-calix[6]arene IN6, the coefficient of HLW purification from ${ }^{137 \mathrm{Cs}}$ after 4 contacts with fresh portions of the extractant was $\sim 10^{3}$ (a decrease from $2.6 \cdot 10^{10}$ to $2.9 \cdot 10^{7} \mathrm{~Bq} / \mathrm{L}$ ). For additional 4 stages of extraction, the activity of

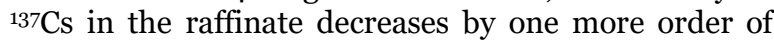
magnitude. The total purification factor from ${ }^{137 \mathrm{Cs} \text { after }}$ 8 stages of extraction was $1.5 \cdot 10^{4}$, and from $\alpha$-emitting radionuclides - about 100, which allows us to transfer this waste to the low-level category, which permits its cementation and surface disposal.

\subsection{Dynamic test}

The principal technological flowsheet of alkaline HLW extraction processing has been developed, including only extraction and striping blocks, without extract washing and recycle solvent regeneration.

Countercurrent flowsheet test using 16-stage of settling mixers extractors (10 extraction and 6 stripping stages) with pulsating phase mixing and simulated alkaline HLW was performed. During 105 hours of test, the setup worked stably; there were neither formation of precipitates, nor poorly separated emulsions, nor mutual phase entrainment. HLW purification factor for ${ }^{137 \mathrm{Cs}}$ and beta-emitting radionuclides of about 500 and a 10 -fold concentration of ${ }^{137} \mathrm{Cs}$ in a strip product were achieved.

The test results confirm the principal possibility of using the solvent based on p-isononylcalix[6]arene for the processing of the "Mayak" PA alkaline HLW [10].

$$
\text { - Initial } \square \text { Raffinate Reextract }
$$

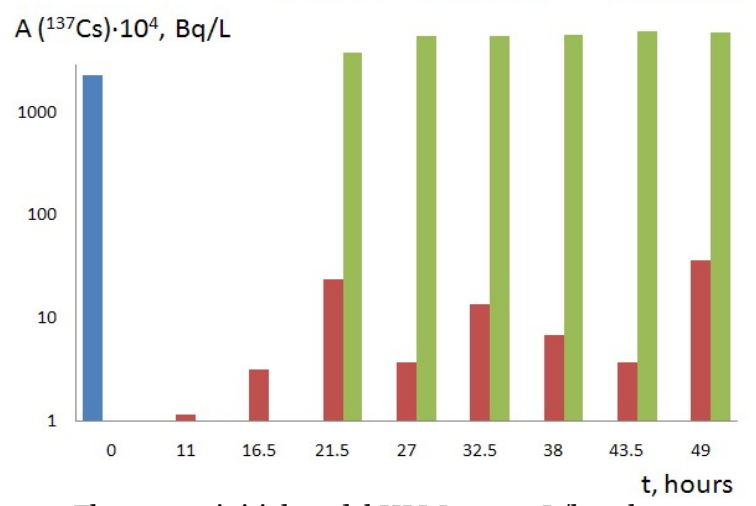

Flow rates: initial model HLW - $90 \mathrm{~mL} / \mathrm{h}$, solvent $90 \mathrm{~mL} / \mathrm{h}$, raffinate $-90 \mathrm{~mL} / \mathrm{h}$, reextract $-45 \mathrm{~mL} / \mathrm{h}$

$$
\text { DF }\left({ }^{137} \mathrm{Cs}\right): 500 \text { - } 114
$$

Figure 4. Maximum extraction of radionuclides (mode I) 
It was noted that the extraction proceeds without any outgassing, the phases mix well and separate quickly. Thus, there is no need to wash the extract and regenerate the circulating extractant. Refusal to wash the extract before the re-extraction operation avoids an increase in the volume of the raffinate.

Dynamic tests included two stages: at the first, maximum extraction of radionuclides (mode I, Fig. 4) was examined, at the second - the maximum concentration of radionuclides (mode II, Fig. 5). Mode I assumed the flow ratio "HLW : extractant" = $1: 1$, and the flow ratio "extract: reextract" = 1:0.5. Mode II assumed the maximum concentration of recovered radionuclides, therefore, the ratio "HLW : extractant" = 1:0.5, and the ratio "extract : reextract" = 1:0.2, which should have provided the minimal final volume of reextract.

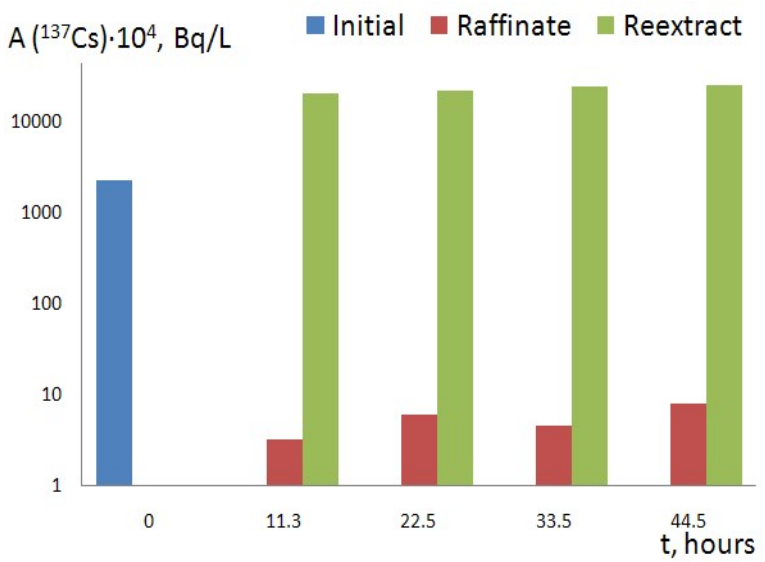

Flow rates: initial model HLW $-90 \mathrm{~mL} / \mathrm{h}$, solvent $-45 \mathrm{~mL} / \mathrm{h}$, raffinate $-90 \mathrm{~mL} / \mathrm{h}$, reextract $-9 \mathrm{~mL} / \mathrm{h}$ DF (137Cs): 710 - 345

Figure 7. Maximum concentration of radionuclides (mode II)

Analysis of the data obtained shows that 10 stages of extraction ensure the extraction of more than $99.8 \%$

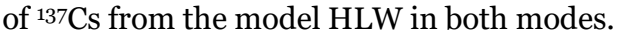

In the mode of maximum extraction (Fig. 4) reextract, containing much lower concentrations of stable salts than HLW, a-active radionuclides with an activity of $(1.3-4.0) \cdot 10^{3} \mathrm{~Bq} / \mathrm{L}$ are found.

The activity of ${ }^{137} \mathrm{Cs}$ in the re-extract in the mode I (Fig. 5) exceeds the initial one by $9-11$ times, in the mode II - by 1.6 - 2.7 times, with the expected concentration coefficients of 10 and 2, respectively. The re-extraction with $1 \mathrm{~mol} / \mathrm{L} \mathrm{HNO}_{3}$ solution in both tested modes was complete and the cesium activity in the circulating extractant was below $10^{5} \mathrm{~Bq} / \mathrm{L}$.

\subsection{Preliminary study of spent extractant composition}

The fresh extractant had a density of $0.8037 \mathrm{~g} / \mathrm{cm}^{3}$ and showed a high separation rate with both alkaline HLW and nitric acid stripping agent. The density of the extractant after testing decreased to $0.7962 \mathrm{~g} / \mathrm{cm}^{3}$. To understand this difference in the density of the extractant before and after the test, the corresponding HPLC chromatograms were recorded and analyzed (Tab. 4).
Table 4. Comparison of HPLC chromatograms of fresh and spent extractant

\begin{tabular}{|c|c|c|c|c|}
\hline \multirow{2}{*}{$\begin{array}{c}\text { Peak } \\
\text { No }\end{array}$} & \multicolumn{2}{|c|}{ fresh } & \multicolumn{2}{c|}{ spent } \\
\cline { 2 - 5 } & $\mathrm{t}, \mathrm{min}$ & $\%$ & $\mathrm{t}, \mathrm{min}$ & $\%$ \\
\hline 1 & 10.18 & 18.849 & 10.27 & 31.999 \\
\hline 2 & 10.71 & 4.930 & 10.63 & 0.700 \\
\hline 3 & 11.19 & 29.532 & 11.28 & 19.282 \\
\hline 4 & 11.43 & 20.205 & 11.50 & 22.577 \\
\hline 5 & 11.72 & 16.331 & 11.82 & 15.099 \\
\hline
\end{tabular}

If we compare the chromatogram "before" and "after" extraction, then, probably, the amount of components has not changed, their ratio has changed. Peaks № 1, 3, 4, and 5, presented in the chromatogram, can be attributed with a high degree of confidence to various forms of octyl radical isomerism in the functional groups of calixarene. Their percentage changes a little before and after the extraction process. Peak № 2, which significantly decreases on the chromatogram in the spent extractant solution, can be attributed to non-cyclic impurities of calixarene remaining after synthesis and purification, and there is a possibility that it is washed out during the circulation of the extractant. Peaks, attributed with the diluents, are not recorded under the detecting conditions.

The data obtained require further more careful study; at this point, it can be assumed that during the tests, a certain amount of diglyme and $m$-NBTF is washed out of the extractant composition, which leads to a decrease in the density of the solution.

\section{CONCLUSION}

$\checkmark \quad$ All hydroxy-calix[n]arenes can be used for ${ }^{137 \mathrm{Cs}}$ and Am extraction from alkaline ( $\mathrm{pH} 12 \div 14)$ media.

$\checkmark$ Hydroxy-calix[6]arenes based solvent demonstrated the highest efficiency for ${ }^{137 \mathrm{Cs}}$ and TRU extraction from real alkaline HLW.

$\checkmark$ Our dynamic test confirm the principal possibility of p-isononylcalix[6]arene based solvent using for the "Mayak" PA alkaline HLW processing.

$\checkmark$ During 105 hours of test, the setup worked stably, without any hydrodynamic problems.

$\checkmark$ HLW decontamination factor for ${ }^{137 \mathrm{Cs}}$ up to 700 and 10 -times ${ }^{137} \mathrm{Cs}$ concentrating in a reextract were achieved.

Acknowledgements: The study was supported by the Russian Science Foundation (project No. 20-6346006). Authors are grateful to M.Yu. Tyupina (SaintPetersburg State University postgraduate) for providing the HLPC chromatograms.

\section{REFERENCES}

1. R. E. Gephart, R. E. Lundgren, Hanford Tank Cleanup: A Guide to Understanding the technical Issues, Columbus (OH), USA: Battelle Press, 1998.

2. S. I. Stepanov et al., "CARBEX Process, A New Technology of Reprocessing of Spent Nuclear Fuel," Russian Journal of General Chemistry, vol. 81, no. 9, article no. 1949, 2011. 
https://doi.org/10.1134/S1070363211090404

3. П.В. Козлов и др., «Варианты реализации технологии предварительной подготовки осветленной фазы ёмкостей-хранилищ накопленных ВАО к отверждению», Вопросы радиационной безопасности, том 70, но. 2, стр. 34-47, 2013.

(P. Kozlov et al., "Implementation Options for the Technology of Preliminary Preparation of Clarified Phase Obtained from Storage Tanks Containing Accumulated HLW for Solidification," Radiat. Saf. Probl., vol. 70, no. 2, pp. 34-47, 2013)

4. B. A. Moyer et al., Next Generation Solvent Development for Caustic-Side Solvent Extraction of Cesium, Rep. ORNL/TM-2014/22, ORNL, DOE, Oak Ridge (TN), USA, 2014.

https://doi.org/10.2172/1167005

5. I. Smirnov et al., "Americium and cesium extraction from alkaline media by calix[8] arenes with p-tertbutyl and isononyl substituents on the upper rim: aggregation effect," Macroheterocyles, vol. 10, no. 2, pp. 196-202, 2017. https://doi.org/10.6060/mhc161070s

6. I. V. Smirnov et al., "Cesium and americium extraction from carbonate-alkaline media with O-substituted p-alkylcalix[8]arenes," J. Radioanal. Nucl. Chem., vol. 314, no. 2, pp. 1257-1265, 2017. https://doi.org/10.1007/s10967-017-5.505-6

7. I. V. Smirnov et al., "Extraction of Cesium-137 and Americium-241 by Calix[n]arenes from CarbonateAlkaline Media," Doklady Chemistry, vol. 479, no. 1, pp. 36-40, 2018.

https://doi.org/10.1134/Soo12500818030035
8. С.Р. Зарипов, «Синтез липофильных каликс[n]аренов для извлечения ионов Cs (I) и Am (III) из щелочных высокоактивных отходов ядерного производства», докторская диссертация, Казанский (Приволжский) федеральный университет, Казань, Россия, 2018.

(S.R. Zaripov, "Synthesis of lipophilic calix[n]arenes for the extraction of $\mathrm{Cs}(\mathrm{I})$ and $\mathrm{Am}(\mathrm{III})$ ions from alkaline high-level nuclear waste," Ph.D. dissertation, Kazan Federal University, Kazan, Russia, 2018.)

Retrieved from:

https://shelly.kpfu.ru/e-

ksu/docs/DISSERTATION/F466590126/Dissertaciya Zaripov S.R o6 11 18.pdf

Retrieved on: Jun. 15, 2021

9. М.Д. Караван, «Экстракционное выделение трансплутониевых, редкоземельных и некоторых осколочных элементов из карбонатно-щелочных растворов с помощью полифенольных макроциклических лигандов», Bопросы радиационной безопасности, том 100, но. 4, стр. 23-34, 2020.

(M. D. Karavan, "Extraction of transplutonium, rareearth and some fission elements from carbonatealkaline solutions using polyphenolic macrocyclic ligands," Radiat. Saf. Probl., vol. 100, no. 4, pp. 23$34,2020)$.

10. I. V. Smirnov et al., "Hydroxycalix[6]arenes with p-isononyl substituents for alkaline HLW processing," J. Radioanal. Nucl. Chem., vol. 326, no. 1 , pp. 675-681, 2020.

https://doi.org/10.1007/s10967-020-07325-Z 